\title{
DOE FinAL TECHNICAL REPORT
}

GRANT: DE-FG03-93ER14311

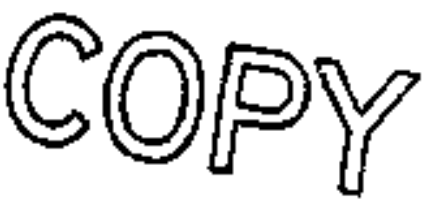

PRNCPAL

INVESTIGATORS: Robert W. Clayton

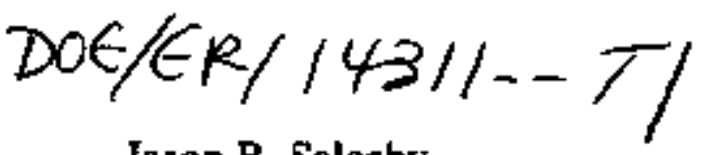
626/395-6909 Fax-626i564-0715

Jason B. Saleeby clay@gps.caltech.edu 626/395-6141 Fax-626/683-0621 jason@gps.caltech.edu

INSTIUTION: Califomia Institute of Technology

Division of Geological \& Planetary Sciences

1200 E. California Blvd.

Pasadena, CA 91125

\section{OBJECTTVES}

The main objective of this study was to determine whether or not the Southem Sierra Nevada Mountain Range is supported by a crustal root. A secondary goal was to evaluate the relationship between the Sierra Nevada Range and the adjoining Death Valley extensional province.

\section{PROJECT DESCRIPTION}

As part of the project, two seismic profiles were executed. The first was a north-south profile running from Ridgecrest to Chafant Valley. The second was an east-west profile from Death Valley to Coalinga. An NPE shot was recorded on the east-west receiver line, and the data were analyzed by forward modeling with a staggered-grid finite-difference code.

Concurrently, we initiated an in-depth study of lower crustal and upper mantle xenoliths hosted by Neogene volcanic rocks of the central and southern Sierra Nevada region. This initial work focused on thermobarometric estimates of representative xerolith samples aimed at understanding the vertical composition of the Sierra Nevada lithosphere.

\section{RESULTS}

The crustal root question was resolved by analysis of data obtained from a shot point in Owens Valley on the east-west profile, along with the recording of the NPE shot on the same line. Shot point 5 (Olancha, Owens Valley) showed that the PmP phase ( $P$ reflection from Moho) has nearly equal travel time when observed to the west (reflection points under the Sierras) or to the east (reflection points under Panamint Valley). The NPE recording also shows that there is no anomalous behavior of $\mathrm{Pg}$ (mid-crust phase) or Pn (Moho phase). 


\section{DISCLAIMER}

Thip report was prepared as an account of work spoacored by an agency of the United States Goverament. Neither the Uaited States Government nar eny agency thereot, wor any of their employes, makes any wamaty, express or implied, or

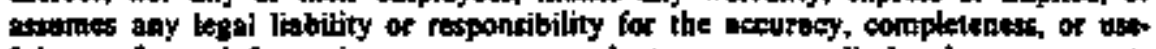

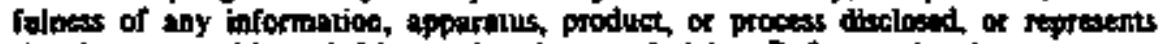

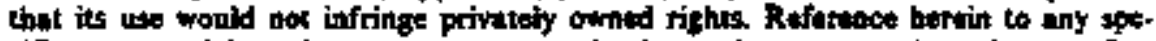
cilit contmetcial product, process, of service by irade name, tradentak, manufacturer, or otherwise does oot neseswarily conatitute or imply its endorseaneat, recontmandition, or favoring by the Uaited States Gowernment or any agensy thereor. The riews and opinions of atthors expresied werein do not acosssenty state or tefuct those of the Unitud States Goverominal of any atency thateot. 


\section{DISCLAIMER}

Portions of this document may be illegible electronic image products. Images are produced from the best avallable original document. 
The above observations indicate that there is no crusta root under the southern Sierra Nevada Mountain Range. This interpretation is also confirmed by the wafeforms produced by the finite-difference modeting, and by the presence of shallow upper mandle xenoliths in Pliocene-Quaternary volcanic rocks.

In contrast, Miocene volcanics carry lower crustal xenoliths which equilibrated over a wide range of pressures, suggesting that a thick crustal root did exist prior to the Pliocene under the Sierra Nevada. Preliminary results indicate that the replacement of a gamet-rich, dense root with hot, partially molten upper mantle can provide enough buoyancy to support the present day mountain range.

The results of this project have been submitted in manuscripts and abstracts as listed below.

Malin, P.E, Goodman, ED., Henyey, T.L, Li, Y-G., Okaya, D.A, and Saleeby, J.B., 1994, Significance of seismic reflections beneath a tilted exposure of deep continental crust, Tehachapi Mountains, California: Joumal of Geophysical Research, v. 100 , p. 2069-2087.

Ducea, M.N., and Saleeby, J.B., 1994, Thermobarometric constraints on the deep crustal-upper mantle composition and structure of the Sierra Nevada, California, from mafic and ultramafic xenoliths: Transactions of the American Geophysical Union, v. 75, p. 583 .

Ducea, M.N., Kistler, R.W., and Saleeby, J.B., 1995, Testing petrogenetic models for the Sierra Nevada lithosphere with REE data on crustal and mantle xenoliths: Geological Society of Anerica Abstracts with Programs, v. 27, p. 15-16.

Saleeby, J.B. and Ducea, M.N., 1996, A three-dimensional picture of the lower crist and upper mantle structure beneath the southern Sierra Nevada (SSN), California Geological Society of America Abstracts with Programs, v. 28,p. 107.

Ducea, M.N., and Saleeby, J.B., 1996, Buoyancy sources for a large, unrooted mountain range, the Sierra Nevada, California; evidence from xenolith thermobarometry: Joutnal of Geophysical Research, v. 101, p. 8229-8244.

Wennicke, B., Clayton, R., Ducea, M.N., Saleeby, J.B., and 16 others, 1996, Origins of high mountains on continents: The Southern Siera Nevada: Science, v. 271, p. 190-193.

KEY WORDS:

Crustal Root, Sierra Nevada 